\title{
CORPORATISATION OF UNIVERSITIES DEEPENS INEQUALITIES BY IGNORING SOCIAL INJUSTICES AND RESTRICTING ACCESS TO HIGHER EDUCATION
}

\author{
R. Dlamini \\ Wits School of Education \\ University of the Witwatersrand \\ Johannesburg, South Africa \\ e-mail: Reuben.Dlamini@wits.ac.za
}

\section{ABSTRACT}

There has been an unprecedented demand for equitable access to post-secondary education post 1994, perhaps because of the change in policies broadening participation of black people in traditional universities in South Africa. The dramatic increase of people of colour attending institutions of higher learning coincided with shrinking government subsidies, which led to universities redesigning their identity according to corporate culture. Thus, they turned to double digit fee increases and persistent long-term outsourcing of services to overcome the problem of funding insecurities. However, it is not clear how corporatization of institutions of higher education enables equitable access and efficient delivery of higher education to the majority of blacks who were previously disadvantaged by apartheid policies. The primary objective of this article is to conduct a meta-synthesis of a systematically retrieved sample of empirical academic literature to present an argument on the systemic deficits in corporatization of higher education and the corporate identity which distort the ideal university. The PRISMA statement is followed to ensure transparent and complete synthesis of the literature reviewed to maintain the integrity of individual studies. Thereafter, the article presents a detailed account of how corporatization of universities deepens inequalities; ignores social injustices and restricts access to higher education. In addition, the article makes a claim that corporatization of universities impairs the academic quality and freedom of the university as well as portrays education as "private good" for self-actualization.

Keywords: corporatisation of universities, education as private good, restricting access to higher education

\section{INTRODUCTION}

The beginning of the twenty-first century exhibits a growing trend in the adoption of the corporate model by universities in South Africa. The corporate model, by its nature, is entrepreneurial and market driven. This has brought a lot of challenges in higher education primarily with regards to the sharing of governance and the inability of young South Africans to access higher education. This article does not argue against entrepreneurship and operational efficiency, but the corrosive effects of corporate culture on institutional autonomy, shared 
governance, and academic freedom. Institutional autonomy, shared governance, and academic freedom are fundamental to the "ideal university" as a social institution engaging in intellectual pursuit (Newman, 1873). This article uses literature to chronicle the effects of corporatization of universities and how they deepen inequalities by ignoring social injustices and restricting access to higher education. In the 1800 s Africa experienced colonization which increased exploration and exploitation of African people. Corporatisation of universities seems to be ushering universities in Africa into an era of modern colonization. Prior to colonization African people implemented situational and informal systems of education that was in line with much needed African scholarship. This education was contextual and responded to the needs of diverse communities.

Thereafter, Europeans inserted themselves into our society and took advantage of our traditional philosophy of Ubuntu. West $(2014,47)$ defines Ubuntu as the "communitarian philosophy that stresses the importance of inter-personal relationships and values such as harmony and care". This philosophy by its nature is communitarian with virtues such as harmony and humanness (Venter 2004; West 2014). Due to our communitarian nature we began accepting and recognizing Europeans despite the clashes of cultural and social identities. Their acceptance resulted in African society reconfiguration in pursuant of neoliberal dogma. The acceptance of neoliberal reforms resulted in South African Higher Education (SAHE) institutions pursuing world class status heralded as a sign of prosperity without considering its potential to accentuate social polarization. The old SAHE institutions had to give in to a new identity imposed by a global phenomenon choreographed elsewhere. The corporatization of universities, which seemed to be in line with neoliberal reforms to tertiary education, was born. However, the neoliberal reforms clash with the ideal African Universities as it "McDonalizes" it. Nadolny and Ryan $(2015,144)$ explain neoliberal ideology as the "corporatization and managerialism practices of university administrators, making universities an easy target for the application of McDonaldization in their quest for the rational service organization". McDonaldization was developed to "imply efficiency, calculability, predictability and increased control through replacement of human initiative with measurable processes in which every task is broken down into its most finite parts so the individual has little or no control" (Nadolny and Ryan 2015, 144). The adoption of the McDonaldization concept by universities in South Africa allowed economic primacy to inform decisions, which is flawed given that access and equity has not been realized. Given the historic background of South Africa being driven by rationality and efficiency is not enough as we face the challenge to transform social structures. According to Ritzer $(1993,371)$ "rationalization has distinctive roots in the western world". 
The European culture has always been in line with the corporate culture whereby the economic primacy of human relationships were precisely calculated and efficiently exploited. In South Africa it would seem that universities are adopting the McDonaldization concept to replace the "ideal" university. Ndlovu-Gatsheni and Chambati (2013) explained that African development and knowledge production were never fully realized beyond some emancipatory pretensions. While being sensitive to internationalization, universities in Africa should be the key players in knowledge development and production informed by the African context instead of continuously importing Western and Eurocentric discourse. The current university in Africa suffers from an inferiority complex as it continues to unpack the global imperial discourse instead of working on globalizing local knowledge to reorient knowledge hierarchies.

It is very difficult to find any correlation between "social justice and access to higher education" and operational efficiency of universities. However, there is a strong correlation between operational efficiency and restricting access to tertiary education. It would seem universities are transitioning from being knowledge producers to rationalized education service providers which is problematic. This has resulted in the rationalization of the education process, standardization of knowledge with Western and Eurocentric piquancy, and promoting functional units efficiencies through streamlining and budget cuts coined as "cost savings". It is clear that corporate culture corrupts some of the principles of shared governance and accountability being redefined as accounting. The corporate model suffers from dominative principles [regulation of knowledge, top-down approach, and cultural individuation] which promote hegemonic tendencies (Borg, Buttigieg and Mayo 2002). Hegemony is the power of dominance over one social class or the dominance of one political unit over other units (Borg et al. 2002). The expectation would have been for Universities in South Africa to be "responsive to the goals of equity, efficiency, democratic participation and development" (Habib 2016, 36). Though we celebrate the diversity and growth in the student enrolment, however throughput is still a reality as only 55 per cent of students who enter the university complete their studies, while fewer than 25 per cent complete their degrees within the minimum allocated time (Dlamini 2016; Habib 2016). Universities need to develop a critical understanding as to why students entering the university will not complete their studies on time. The state of affairs must be socially just to ensure a fair distribution of higher education benefits across communities, especially among historically disadvantaged groups.

The growing influence of corporate culture in higher education makes universities look like subsidiaries for business enterprises instead of making universities the Bureau of Knowledge Production and Licensing Degrees. Business is about domination and profit making, which is divorced from the "ideal university" as education is a public good. According 
to Dlamini $(2016,54)$ "universities must not react to the convenience of bourgeois culture". The value of knowledge production should outweigh world class status, corporate power, and market values. Therefore, we cannot afford to lose higher education to corporate culture whereby shared governance is marginalized with demands to optimize dividends for shareholders. According to Giroux $(2009,2)$ higher education "may be one of the few institutions left that still fosters critical inquiry, public freedom, and common deliberation, simultaneously keeping alive the promise of a democratic ethos and politics". The danger of the corporate model is its politicization of research as a way to generate income and allow market pressures to influence institutional decision-making. Research must help universities in Africa to unlock the knowledge production space to disrupt the ongoing legacies of colonialism. Giroux asserts that:

"Higher education is increasingly abandoning its role as a democratic public sphere as it aligns itself with corporate power and market values. Instead of being a space of critical dialogue, analysis, and interpretation, it is increasingly defined as a space of consumption where ideas are validated in instrumental terms and valued for their success in attracting corporate and government funding" (Giroux 2009, 670).

South African universities are not unique to such transition. They appear to be suffering from both identity [world class status] and legitimacy by wanting to be among the top 100 universities in the world. In South Africa, universities are replacing public intellectuals with privatized A-Rated international scholars to serve "under the influence of managerial modes of governance and market values that mimic the logic of Wall Street" (Giroux 2009, 3). Therefore, my argument is that the corporatization of universities is undermining tertiary education as it focuses on world class status [market value], identities [among top 100 universities], and social relations. The debate about value for corporatization of universities is critical as there are many questions that still need answers. We should not use corporatization as a response and proactive way to becoming world class universities. Our historical context as a country should matter as universities should serve the public as a bastion of democratic inquiry and intellectual engagement.

Therefore, restricting access to higher education will further skew the uneven distribution of talent and human capital (Dlamini 2016). Access is restricted through exorbitant fees that only serve to fund world-class status, which comes with obligations and is divorced from the realities of South African universities. The efforts being made to achieve a kind of iconic status are not in line with achieving social justice and access to higher education by majority blacks who were previously disadvantaged by apartheid policies. History tells us that universities in 
South Africa cannot afford to be redesigned according to the logic of market economics as that will be a reaction to the convenience of bourgeois culture and commodification of knowledge. Thus, this article argues against further transforming of education "into a commodity, students becoming more like consumers, faculty into entrepreneurs, and institutions of higher learning into storefronts for knowledge" (Chau 2010, 178). The reality in South Africa is that a majority of the people previously disadvantaged by apartheid policies have fewer resources to spend on higher education. Therefore, we must refrain from cultures that will contribute to widening the access gap and create environments that broaden participation to tertiary education. The corporatization of universities suffers from systemic deficits which restrict access to higher education. The papers reviewed led to the organization of this article according four operative concepts: deficit of corporatization of universities, institutional culture of higher education, transformation, and deconstruction.

\section{SYSTEMIC DEFICIT OF CORPORATIZATION OF UNIVERSITIES}

The corporatization of universities has increased the regularization of knowledge production and allowed for the reconfiguration of students as consumers. Clark $(1960,569)$ ascertains that "a major problem of democratic society is inconsistency between encouragement to achieve and the realities of limited opportunity". In a democratic South Africa we must create means for people to develop and succeed instead of creating a situation of "denial and failure" (Clark 1960, 569). Increasing access to local universities increases education, wage dispersion, and cultural capital. We cannot afford the preservation of the existing pattern of social relations. Unless we forget that in South Africa racial exploitation has been called by various great names such as "the peculiar institution, the social system, and the impediment" (Magubane 1979, 225) and now we are experiencing new terminologies such as transformation born in the era of corporatization of universities.

In my analysis the new monster, corporatization, assumes new characteristics. Therefore we need to know about the people that are accepting corporate culture as the future of our universities. Given South Africa's historic past, the corporatization of universities seems to suffer from the Afrikaner's perception of reality which was "faulty logic and partly irrational mixture of mystical beliefs, aggressive romanticism, and traumatic fears which cannot be upheld in today's world" (Magubane 1979, 226). The obvious contradiction with our universities is the adoption of corporate culture which is synonymous with isolation and segregation. Magubane's point is that,

\footnotetext{
"When the progress of reason [...] is impeded, when existing and maturing possibilities for
} 
society's further advancement, for further growth and development of all its members are sacrificed in favour of the interest of the dominant class in the continuation of the established social order - when, in other words, the particular interest of the ruling class comes into conflict with the interests of society as a whole" (Magubane 1979, 232).

The corporatization of higher education institutions undermines the new structures created in the Constitution of South Africa to allow social justice and equitable access to tertiary education. Any model or framework that perpetuates class structure through hierarchical orders is not suitable for a democratic society. Furthermore, any policies promoting a socially unjust South Africa are not acceptable today as they preserve hegemony. The corporate culture in our universities creates a decadent civilization. By adopting the corporate model we are saying that previously disadvantaged people should go back to the "reserves where they come into their own ... under white trusteeship" (Magubane 1979, 254) because tertiary education is for a selected few. In this day and age it is absolutely naïve to create an environment that will indefinitely deny previously disadvantaged people the privileges of modern life. In demand for great humanity for all, the \#FeesMustFall ${ }^{1}$ movement was born. This was a student led protest in response to double digit increase in fees at South African universities and the corporatization of universities. The double digit increase in fees at South African universities did not take into account the rising income inequality and the persistent long-term unemployment.

\section{THE INSTITUTIONAL CULTURE OF HIGHER EDUCATION}

The current institutional culture of higher education neither takes into consideration human experience nor strives to correct the unfairness of the past. According to Suransky and Van der Merwe $(2016,578)$, "today, the reality is still far removed from the post-apartheid vision of a democratic, non-racial and non-sexist higher education system". Therefore the discourse in African universities is influenced by people living thousands of miles away from our realities. The \#FeesMustFall movement challenges our universities to decolonize so that they are relevant to the South African context.

This article seeks to initiate a straight talk on the deleterious grip that corporate culture has had on universities in South Africa with no regard to the challenges facing the country and its citizens. In order to weather the storm created by the corporatization of universities, we need to ask fundamental questions about the "ideal university" (Newman 1873). University senior management and council must stop abrogating faculty governance and devaluating faculty, staff and students as members of the university's community. The New York Times in January 4, 1998 was spot on when it reported that: 
"... The danger today is that the administrations that now set policy at most universities are increasingly tempted to act as if they are running a business-letting profit motives drive educational policy. In such a climate, revenue-generating programs and inexpensive part-time professors are winning out over a committed faculty, good libraries, and small classes. American universities have achieved their international prominence precisely because they have, until now, recognized the value of free inquiry, open expression, and discovery that is driven not by financial gain but by broader social ends ...." (Shapiro 1998).

University Vice-Chancellors and Principals are becoming managers of the existing bureaucracy. Therefore, to steer the ship back on course we need an organizational model that promotes shared governance. An autocratic approach will not survive in higher education as it is exploitative and is top-down in nature. The future of the university in South Africa should not abide to the dictates of the business elites due to the financial commitment they make to the universities in the form of endowments. The erosion of the ideal university culture through the rise of corporate presence results in an oversupply of prospective bureaucrats. Financial backings have allowed business partners to force down the throat of tertiary institutions their ideologies inspite of their relevance to the core mission of the university.

Currently, university tuition fees have grown at rates that have far outpaced the ability for parents, guardians, and students to afford tertiary education. The plea is that tuition fees should not be a determining factor to the pursuance of post-secondary education. The rapid increase in the price to attend tertiary education is discouraging and hazardous in our society. It is clear that the relocation of colonial masters back to Europe did not amount to decolonization of Africa. Ndlovu-Gatsheni and Chambati (2013) quoting (Grosfoguel 2007, 219) note:

"The heterogeneous and multiple global structures put in place over a period of 450 years did not evaporate with the juridical-political decolonization of the periphery over the past 50 years. We continue to live under the same 'colonial power matrix'. With juridical political decolonization we moved from a period of 'global colonialism' to the current period of 'global coloniality". (Grosfoguel 2007, 219).

\section{TRANSFORMATION}

The quest for transformation has been hampered by the in-adequate and simplistic theories with links to the Western and Northern hemisphere. As we think about transformation it is important to understand how African universities came to be dominated by Western and Eurocentric knowledge. Though it is not explicitly stated, it is clear that dictatorial means were used. Therefore, we need to deal with structures because racialized social systems are hierarchical. Benedict $(1945,87)$ defined racism as "the dogma that one ethnic group is condemned by nature to congenital inferiority and another group is destined to congenital superiority". According to 
Fanon $(1967,77)$ the "habit of considering racism as a mental quirk, as a psychological flaw, must be abandoned". We know very well that the Western and Europeans including white minority in South Africa used exploitative measures to raise their social standing. McLean $(1999,8)$ quoting Kallaway $(1984,8)$ observed,

"The colonised people of Southern Africa were not simply conquered in a military sense; did not only lose their political independence; were not simply divorced from an independent economic base; were not just drawn into new systems of social and economic life as urban dwellers or wage labour. Though all these aspects of the process of colonization have great importance, the key aspect to be noted here is that it also entailed cultural and ideological transformation, in which the schools were major agents."

It is high time we unchain ourselves from the Western-Euro-controlled education and create education systems that are responsive to the needs of the continent. Keto $(1990,19-20)$ describes those indigenous programs of teaching and learning:

"African societies in South Africa had invariably created their own institutions and processes of socialization and education before the Dutch settlers arrived in 1652. That process of education began by learning of the young from family members. Later, the young were trained in manners, roles, responsibilities, and history as well as the importance of military and fighting skills."

Until we undo all the set of beliefs that are discriminative and overlook the fact that "all men are created equal" and we are a multicultural society, we will not resolve issues of racism and unfair social structures. The disregard of inclusivity was inherited from the discriminative system which decided to regulate knowledge and uphold dominative culture. We must continue the conversation about the meaning of decolonization and struggles for the recognition of indigenous intellectuals. In our approach we must not extend innocence to apartheid and further appropriate Western tendencies.

\section{DECONSTRUCTION}

Today universities are confronted with structures enacted over a period of hundreds of years and these structures suffer from epistemological patterns of domination and exploitation. South African universities need to start practicing acts of resurgence. The efforts to continuously serve our relationships with the West are disruptive because we miss opportunities to connect with the local context and restore our identity. We need to confront colonial structures that displace knowledge production and governance informed by local context. One of the goals of the Higher Education Act (Department of Education1997, 1.27, 2.37) is, 
"To conceptualise (and) plan ... higher education in South Africa as a single, co-ordinated system", "ensure diversity in its organisational form and in the institutional landscape", "diversify the system in terms of the mix of institutional missions and programmes that will be required to meet national and regional needs in social, cultural and economic development", and "offset pressures for homogenisation".

Therefore, reconstruction is not an option if we are to achieve the goals of the Higher Education Act, the National Development Plan, and the Freedom Charter. If universities remain in their current form, then achieving the education transformation agenda is a distant goal. We need to create universities that are progressive and "congruent with the core principles of social equity and redress, social justice, democracy and development" (Badat 2010, 5). The \#FeesMustFall movement is an opportunity for universities to reconfigure their structures to meet the needs of a new democracy that is inclusive and accessible to all qualifying citizens. The legacy of the apartheid system must be eradicated at all cost to advance social equity.

Birnbaum (2007) suggests that higher education should be looked at as a social institution. However, at the crux of the social demand for higher education is the demand for free, quality and decolonized education. The university should value human dignity and human rights given the country's historical background. Therefore our universities should not turn to corporate culture for solutions. According to Giroux $(2002,425)$,

"Neoliberalism approach is the most dangerous ideology of the current historical moment .... He maintains that corporate culture functions largely to either ignore or cancel out social injustices in the existing social order by overriding the democratic impulses and practices of civil society through an emphasis on the unbridled workings of market relations."

This neoliberal approach is hazardous to South African democratic society, where all citizens are valued. The ideal university should always see itself in the context of the citizens. According to Dlamini $(2016,55)$, "the South African space is characterized by scarce resources and competing priorities for families to be able to send their children to university". With corporatization of higher education associated with world class universities it will be very difficult for the underprivileged to send their qualified children for tertiary education. According to Habib $(2014,2)$ the South African Constitution "demands that its public institutions simultaneously address the historical disparities bequeathed by Apartheid and build a collective national identity". Thus it is not clear how the corporatization of universities enables equitable access and efficient delivery of higher education to those who were previously disadvantaged by apartheid policies. 


\section{CONCLUSION}

The cult of corporate culture inspires fear as universities are being transformed to Bureau of Licensing Degrees. There is an understanding that government funding has come to a "screeching halt" and finding new ways to fund education is inevitable. However, that should not happen at the expense of shared governance and democratic principles. According to Schiller $(1991,3)$ "the drive to privatize and bring under corporate management as many elements of economic and social activities as possible in the last half century has tipped the balance of democratic existence to an uncomfortable precariousness". It is clear that the crux of the matter is under funding of universities, therefore meaningful and balanced partnerships must prevail to make education accessible to all. It must be known that this article does not argue for the university to remain sacrosanct given the current situation. We must avoid the cooptation of our institutions of higher learning by the dogmas of neoliberalism which is socially dislocated from the South African context, unless we adopt the utopian view of being a university in African contexts. Maybe we still need to ask questions: What does it mean to be an African university? Post \#FeesMustFall, what might the university become? What constraints are pressing upon the university? And what steps need to be taken to address the constraints? Given all the constraints faced by universities, they should never become subsidiaries of business enterprise.

Senior management must commit to democratic principles and find ways to integrate all communities ensuring that "race" and socio-economic status is not a barrier to tertiary education. University executives need to share authority and stop acting like they have a fiduciary obligation to the corporate world for their survival. Yes, government has a bigger role to play by making sure those issues of access and tertiary education funding are comparable to other BRICS countries. The academic-corporate relationships have existed for a long time, however it is not clear how they are built and the extent they enhance teaching and learning. From my view it is clear that they corrupt the inclusive academic culture prevalent before the commodification of higher education.

The relationship between universities and the industry should not only focus on bringing in money and increasing numbers of students. The relationship should be characterized by sharing of knowledge and contribution towards the development of relevant programmes to educate and empower students with skills to transform and enhance their educational experience. The entrepreneurial activities are welcome, however not at the expense of academic quality and freedom of the university. Those who suffered the worst excesses of capitalist exploitation bequeathed by apartheid must be compensated through tertiary education access and deactivate irrational and unfair social structures. 


\section{NOTE}

1. http://www.breakingnews.com/topic/fees-must-fall-tuition-hike-protests-in-south-africa/

\section{REFERENCES}

Badat, S. 2010. The challenges of transformation in higher education and training institutions in South Africa. Paper commissioned by Development Bank of Southern Africa. https://www.nihss.ac.za/content/document/challenges-transformation-higher-education-andtraining-institutions-south-africa (Accessed 23 June 2017).

Benedict, Ruth F. 1945. Race and racism. London, England: Routledge and Kegan Paul.

Birnbaum, R. 2007. No world-class university left behind. International Higher Education 47: 7-9.

Borg, C., J. Buttigieg and P. Mayo. (Eds.). 2002. Gramsci and education. New York: Rowman \& Littlefield.

Clark, B. R. 1960. The "cooling-out" function in higher education. American Journal of Sociology: 569576.

Chau, P. 2010. Online higher education commodity. Journal of Computing in Higher Education 22(3): $177-191$.

Department of Education. 1997. A programme for the transformation of higher education. Education White Paper 3. Pretoria, DOE.

Dlamini, R. 2016. The global ranking tournament: A dialectic analysis of higher education in South Africa. South African Journal of Higher Education 30(2): 53-72.

Fanon, Frantz. 1967. Black skin, white masks. New York: Grove Press.

Giroux, H. A. 2009. Democracy's nemesis: The rise of the corporate university. Cultural Studies? Critical Methodologies 9(5): 669-695.

Giroux, H. 2002. Neoliberalism, corporate culture, and the promise of higher education: The university as a democratic public sphere. Harvard Educational Review 72(4): 425-464.

Grosfoguel, R. 2007. "The epistemic decolonial turn: Beyond political-economy paradigms." Cultural Studies 21(2-3) March/May: 211-223.

Habib, A. 2016. Transcending the past and reimagining the future of the South African university. Journal of Southern African Studies 42(1): 35-48.

Habib, A. 2014. Transcending the past and reimagining the future of the South African university. Inaugural Lecture. http://www.wits.ac.za/files/5b4ds_167906001417166876.pdf (Accessed 1 December 2014).

Kallaway, P. 1984. "Introduction". In Apartheid and education: The education of black South Africans, ed. P. Kallaway. Johannesburg: Ravan Press.

Keto, T. C. 1990. Pre-industrial education policies and practices in South Africa. Pedagogy of domination: Toward a democratic education in South Africa: 19-42.

Magubane, B. 1979. The political economy of race and class in South Africa (Vol. 506). New York: Monthly Review Press.

McLean, D. 1999. Neocolonizing the mind? Emergent trends in language policy for South African education. International Journal of the Sociology of Language 136(1): 7-26.

Nadolny, A. and S. Ryan. 2015. McUniversities revisited: A comparison of university and McDonald's casual employee experiences in Australia. Studies in Higher Education 40(1): 142-157.

Ndlovu-Gatsheni, S. J. and W. Chambati. 2013. Coloniality of power in postcolonial Africa. Myths of decolonization. CODESRIA Book Series.

Newman, J. H. [1852-9] 1873. The idea of a university. Defined and illustrated. London. Longmans, 
Green and Co. (New Impression 1907).

Ritzer, G. 1993. The McDonaldization of society: An investigation into the changing character of contemporary social life. Newbury Park, CA: Pine Forge Press.

Schiller, H. I. 1991. Culture, Inc: The corporate takeover of public expression. Oxford University Press on Demand.

Shapiro, J. 1998. Beyond the culture wars. https://www.nytimes.com/books/98/01/04/reviews/ 980104.04shapirot.html

Smart, J. C., G. D. Kuh and W. G. Tierney. 1997. The roles of institutional cultures and decision approaches in promoting organizational effectiveness in two-year colleges. Journal of Higher Education: 256-281.

Suransky, C. and J. C. van der Merwe. 2016. Transcending apartheid in higher education: Transforming an institutional culture. Race Ethnicity and Education 19(3): 577-597.

Venter, E. 2004. The notion of ubuntu and communalism in African educational discourse. Studies in Philosophy and Education 23(2): 149-160.

West, A. 2014. Ubuntu and business ethics: Problems, perspectives and prospects. Journal of Business Ethics 121(1): 47-61. 